\title{
ENOXAPARIN SUPPRESSES THROMBIN FORMATION AND ACTIVITY DURING CARDIOPULMONARY BYPASS IN BABOONS
}

Nicolas Gikakis, BSE ${ }^{\mathrm{a}}$

A. Koneti Rao, $\mathrm{MD}^{\mathrm{b}}$

Shinji Miyamoto, MDa

Joseph H. Gorman III, MD

Mohammed M. H. Khan, MD

Harry L. Anderson MD

C. Eric Hack, $\mathrm{PhD}^{\mathrm{c}}$

Ling Sun, $\mathrm{MD}^{\mathrm{b}}$

Stefan Niewiarowski, MD, $\mathrm{PhD}^{\mathrm{b}}$

Robert W. Colman, $\mathrm{MD}^{\mathrm{b}}$

L. Henry Edmunds, Jr, MD
Objective: This study tests the hypotheses that enoxaparin, a low molecular weight heparin and potent inhibitor of factor Xa, alone or in combination with standard heparin, inhibits thrombin formation and activity and modulates complement activation and neutrophil elastase release during cardiopulmonary bypass in baboons. Methods: After preliminary studies to determine doses and possible species differences to anticoagulants and protamine, 27 anesthesized baboons had normothermic cardiopulmonary bypass with standard, unfractionated, porcine intestinal heparin, enoxaparin, or a combination of heparin and enoxaparin. Protamine in appropriate doses was used to reverse anticoagulation. Blood samples were obtained at 6 time points. Activated clotting times were monitored; template bleeding times were measured before and up to 24 hours after cardiopulmonary bypass. Results: Hemodynamic measurements were not affected by the anticoagulant. Activated clotting times remained above 400 seconds throughout bypass, and no clots were observed. The anticoagulant did not alter platelet count, aggregation to adenosine diphosphate, release of $\beta$-thromboglobulin, release of neutrophil elastase, or complement $\mathrm{C} 3 \mathrm{~b} / \mathrm{c}$ and $\mathrm{C} 4 \mathrm{~b} / \mathrm{c}$. Enoxaparin alone, but not in combination, significantly reduced plasma levels of prothrombin fragment F1.2, fibrinopeptide A, and thrombin-antithrombin complexes but prolonged template bleeding times for more than 24 hours. Conclusion: Enoxaparin significantly reduces thrombin formation and activity during cardiopulmonary bypass but does not suppress complement activation and neutrophil elastase release and is not adequately reversed by protamine after bypass. (J Thorac Cardiovasc Surg 1998;116:1043-51)
$\mathrm{D}$ espite large doses of heparin, thrombin circulates during cardiopulmonary bypass $(\mathrm{CPB})$ and cardiac surgery with $\mathrm{CPB}$. Thrombin is a powerful enzyme that not only cleaves fibrinogen to fibrin but also directly

From the Department of Surgery, University of Pennsylvania Medical Center, Philadelphia ${ }^{a}$; the Sol Sherry Thrombosis Research Center, Department of Physiology, Temple University, Philadelphia ${ }^{\text {b }}$, and the Central Laboratory of the Netherlands Red Cross Transfusion Service and Laboratory for Experimental and Clinical Immunology, University of Amsterdam, The Netherlands. ${ }^{\mathrm{c}}$

Supported by HL47186 from the National Heart Lung Blood Institute, National Institutes of Health, Bethesda, Md.

Received for publication Feb 12, 1998; revisions requested April 15, 1998; revisions received July 14, 1998; accepted for publication July 21, 1998.

Address for reprints: L. Henry Edmunds, Jr, MD, Department of Surgery, Hospital of the University of Pennsylvania, Six Silverstein, 3400 Spruce St, Philadelphia, PA 19104.

Copyright (C) 1998 by Mosby, Inc.

$0022-5223 / 98 \$ 5.00+0 \quad \mathbf{1 2 / 1 / 9 3 2 9 5}$ stimulates platelets, endothelial cells, and other important constituents of blood coagulation. ${ }^{2}$ Heparin directly inhibits circulating thrombin and partially inhibits thrombin formation by weakly inhibiting factor Xa and factor IXa ${ }^{3}$; it inhibits thrombin activity within blood clots only at very high concentrations. ${ }^{4}$ Inhibition of thrombin formation, as opposed to inhibition of thrombin after it is formed, offers the prospect of down-regulating the overall coagulation stimulus during cardiac operations and surmounting disadvantages of unfractionated heparin.

The intrinsic and extrinsic coagulation pathways converge by converting factor $\mathrm{X}$ to factor $\mathrm{Xa}$, which initiates formation of the prothrombinase complex and converts prothrombin to thrombin., 2,5 Several peptides, found in leeches and spiders, bind factor Xa in nanomolar concentrations, ${ }^{6}$ but recombinant forms of these proteins fail to suppress thrombin formation during in vitro extracorporeal perfusion. ${ }^{7}$ Compared with standard 
heparin, low molecular weight heparins are more potent inhibitors of factor $\mathrm{Xa}$ in vivo ${ }^{8}$ and better suppressors of thrombin generation in patients with deep venous thrombosis. ${ }^{9}$ Low molecular weight heparin has also been used for clinical cardiac operations. ${ }^{10-12}$

In a previous study we observed that the low molecular weight heparin, enoxaparin, completely suppressed complement activation and neutrophil elastase release during in vitro, simulated, extracorporeal recirculation of fresh human blood. ${ }^{7}$ The same study also showed that thrombin formation and activity, as measured by the generation of the prothrombin fragment F1.2 and fibrinopeptide A, was attenuated by enoxaparin as compared with standard porcine heparin. ${ }^{7}$ The present in vivo study tests the hypothesis that anticoagulation with enoxaparin or a combination of enoxaparin and standard heparin attenuates thrombin formation and activity and also reduces complement formation and neutrophil elastase release during CPB in baboons.

\section{Methods}

Preliminary in vitro studies. Enoxaparin (Clexane; Rhone-Poulenc Rorer, Vitry Sue Seine, France) is a depolymerized heparin with a molecular mass of 3500 to $5500 \mathrm{kD}$. In blood from 3 baboons, 12 enoxaparin concentrations between 0 and $1500 \mathrm{U} / \mathrm{mL}$ (approximately $1 \mathrm{mg}=100 \mathrm{IU}$ anti-factor Xa activity) were titrated against activated clotting times to determine the dose required to increase the activated clotting time to just over 600 seconds. This dose $(10 \mathrm{U} / \mathrm{mL})$ was used to calculate the enoxaparin dose for in vivo studies.

In 3 baboons, the dose of enoxaparin was given intravenously (blood volume assumed 0.08 times body weight) to raise the activated clotting time to $625 \pm 70$ seconds. Sixty minutes later, the activated clotting time was $353 \pm 13$ seconds. Ten and 60 minutes after protamine $(4 \mathrm{mg} / 100 \mathrm{U}$ enoxaparin), activated clotting times were $195 \pm 4$ and $147 \pm$ 9 seconds, respectively.

The effects of standard porcine intestinal heparin and enoxaparin on complement $\mathrm{C} 1-\mathrm{s}$ and factor Xa inhibition in human and baboon blood were compared. Fresh human $(n=2)$ and baboon $(n=2)$ peripheral venous blood was drawn directly into test tubes containing 3 different anticoagulants: porcine heparin $(3.75 \mathrm{U} / \mathrm{mL})$, enoxaparin $(17.5 \mathrm{U} / \mathrm{mL})$, and $3.8 \%$ sodium citrate (10\% citrate/90\% blood by volume). Blood was centrifuged at $2000 \mathrm{~g}$ for 20 minutes; the supernatant was further centrifuged at $15,000 \mathrm{~g}$ for 10 minutes; this supernatant was divided into aliquots and stored at $-80^{\circ} \mathrm{C}$ until studied. For analysis aliquots $(12.5 \mu \mathrm{L})$ of plasma were incubated with 100 $\mu \mathrm{L}$ of $0.1 \mathrm{U} / \mathrm{mL}$ FXa (Enzyme Research Laboratories Inc, Southbend, Ind) in microtitre plate wells and incubated for different time intervals (0 to $10 \mathrm{~min}$ ). Chromogenic substrate S2222 (Chromogenix, Franklin, Ohio) was added and absorbance was read at $405 \mathrm{~nm}$ after 12 minutes.

For C1-s inhibition plasma or phosphate-buffered saline solution (PBS; $0.1 \mathrm{~mol} / \mathrm{L}$ containing $0.15 \mathrm{NaCl}, \mathrm{pH} 7.4$ ) and substrate, S2314 (Chromogenix) were preincubated at $37^{\circ} \mathrm{C}$ for 2 minutes. Activated human C1-s $(1.0 \mu \mathrm{mol} / \mathrm{L}$, final concentration; Enzyme Research Laboratories Inc) was added to yield a total volume of $200 \mu \mathrm{L}$ and incubated at $37^{\circ} \mathrm{C}$ in a water bath. The final concentration of S2314 was $0.5 \mathrm{~mol} / \mathrm{L}$. The reaction was stopped at $0,5,10$, and 30 minutes by adding 100 $\mu \mathrm{L} 50 \%$ (vol/vol) acetic acid. Triplicate samples $(80 \mu \mathrm{L})$ were placed in a disposable nonsterile assay plate (96 well; Corning, Inc, Corning, NY) and measured at $405 \mathrm{~nm}$ by the enzymelinked immunosorbant assay reader (Multiscan Biochromatic Plate Liter; ICN Pharmaceuticals, Huntsville, Ala).

In vivo studies. Thirteen juvenile baboons (Papio annubis) weighing 10 to $23 \mathrm{~kg}$ were used. The animals were divided into 3 groups: standard procine intestinal heparin $(300 \mathrm{U} / \mathrm{kg}$; Elkins-Sinn, Inc, Cherry Hill, NJ) control (group 1, $\mathrm{n}=10$ ); enoxaparin ( $800 \mathrm{U} / \mathrm{kg}$; group $2, \mathrm{n}=8)$; and a combination of porcine heparin $(225 \mathrm{U} / \mathrm{kg})$ and enoxaparin $(200 \mathrm{U} / \mathrm{kg}$; group $3, n=9)$. Baboons were studied when the mandated rest period of 6 to 8 weeks between studies expired or when new animals completed quarantine; 3 animals were studied thrice; 8 animals, twice; and 2 animals, once. Activated clotting times with the use of kaolin were monitored throughout the study, and all times increased over $500 \mathrm{sec}$ with each bolus dose of anticoagulant. This study was approved by the University of Pennsylvania Committee on Animal Care and Utilization (IACUC).

For each CPB experiment, the baboon was placed in a squeeze cage, sedated with $10 \mathrm{mg} / \mathrm{kg}$ ketamine hydrochloride intramuscularly, and induced with $5 \mathrm{mg} / \mathrm{kg}$ thiopental sodium intravenously. The animal was intubated; general anesthesia was maintained with inhalational isofluorane. The right or left side of the neck and both groins were prepared and draped appropriately for sterile cutdown and cannulation of vessels. Hemodynamic monitoring was accomplished with an arterial line with a 22-gauge catheter placed in the femoral artery, and a $5 \mathrm{~F}$ balloon-tipped pulmonary artery catheter placed via a femoral vein. After anticoagulation, a $10 \mathrm{~F}$ to $14 \mathrm{~F}$ Bio-Medicus (Medtronic Bio-Medicus, Eden Prairie, Minn) wire-wrapped, polyurethane catheter was introduced into the jugular vein and advanced into the right atrium. A similar, but shorter $8 \mathrm{~F}$, arterial catheter for reinfusion was inserted into the femoral artery.

Each bypass circuit was assembled with silicone-rubber tubing (Dow Corning Corporation, Midland, Mich), incorporating a bubble oxygenator (Bentley 5/Pediatric; Baxter Healthcare, Inc, Irvine, Calif), an arterial filter (Intersept Pediatric; Medtronic, Inc, Anaheim, Calif), and a roller pump (model 13400; Sarns/3M, Ann Arbor, Mich). ${ }^{13}$ The circuit was primed with approximately $500 \mathrm{~mL}$ of Normosol solution (Abbott Laboratories, North Chicago, Ill). Normothermic CPB began at a flow rate of $50 \mathrm{~mL} / \mathrm{kg} / \mathrm{min}$ (approximately one half of the baboon's resting cardiac output), and perfusion was maintained for 60 minutes. Ten minutes after CPB ended, protamine was given for total doses of anticoagulant as follows: $1 \mathrm{mg} / 100 \mathrm{U}$ heparin; $4 \mathrm{mg} / 100 \mathrm{U}$ enoxaparin.

Sampling times. Six blood samples (15 to $20 \mathrm{~mL}$ each) were obtained at baseline before anticoagulation (time-point 
labeled BASELINE); after anticoagulation (HEPARIN); 5 minutes after starting CPB (START); 5 minutes before stopping CPB (END); 10 minutes after protamine $(3 \mathrm{mg} / \mathrm{kg}$; Elkins-Sinn, Inc, Cherry Hill, NJ) (PROTAMINE); and 60 minutes after time-point PROTAMINE (PROTAMINE-60). Some additional hematologic measurements were made 120 and 180 minutes after protamine and 24 hours later.

Measurements. Heart rate by electrocardiogram, systemic (systolic, diastolic, mean) arterial blood pressures, central venous pressure, pulmonary arterial pressure, and pulmonary capillary wedge pressure were continuously monitored. Intermittent thermodilution cardiac outputs were measured in duplicate before and after CPB. Blood samples were assayed for hematocrit, platelet count, white blood cell count, platelet aggregation to adenosine diphosphate (ADP), $\beta$-thromboglobulin $(\beta \mathrm{TG})$ release, release of neutrophil elastase, complement glycoproteins $\mathrm{C} 3 \mathrm{~b} / \mathrm{c}$ and $\mathrm{C} 4 \mathrm{~b} / \mathrm{c}$, prothrombin fragment $\mathrm{F} 1.2$, thrombin-antithrombin complex (TAT), and fibrinopeptide A (FPA). Template bleeding times were measured at 6 time points. Dilution of formed blood elements and plasma proteins were corrected with the use of hematocrit. The total amount of blood withdrawn was limited to less than $10 \%$ of body weight (120 to $180 \mathrm{~mL}$ ) for each experiment, and blood remaining in the perfusion circuit was reinfused at the end of CPB.

Hematocrit and platelet count assays were performed on whole blood. Platelets were counted by phase microscopy or by Coulter Counter (model STKR; Coulter Electronics Inc, Hileah, Fla) in triplicate. After correction for hemodilution, platelet counts were expressed as a percentage of BASELINE values. Platelet aggregation to ADP was studied with a Payton aggregometer (model 440; Chrono-Log, Inc, Havertown, Pa). Platelet-rich plasma and platelet-poor plasma were prepared from citrated blood $(10 \mathrm{~mL}$ with $10 \%$ by volume of $3.8 \%$ citrate) by differential centrifugation at $150 \mathrm{~g}$ for 10 minutes and $13,600 \mathrm{~g}$ for 5 minutes, respectively. Before studies of aggregation, the platelet count of platelet-rich plasma was adjusted to $150,000 / \mu \mathrm{L}$ by dilution with platelet-poor plasma. The concentration of ADP required to produce complete secondwave aggregation was measured; complete second-wave aggregation was assumed when light transmission was $62.5 \%$ or greater within 5 minutes. ${ }^{14}$ Platelet aggregation is reported as a percentage and normalized to the concentration of ADP required to obtain full aggregation of the baseline sample. The percent aggregation observed at that ADP concentration in subsequent samples is recorded.

Template bleeding times were measured in duplicate on the forearm at the same time points as blood samples, except during $\mathrm{CPB}$, and were measured 120 and 180 minutes and 24 hours after PROTAMINE (time points labeled PROTAMINE120, PROTAMINE-180, and 24 hours) with a blood-pressure cuff inflated to $40 \mathrm{~mm} \mathrm{Hg}$. The Simplate II (Organon Teknika Corporation, Durham, NC) lancet was used to create reproducible skin incisions for determinations of bleeding times.

For plasma $\beta$-TG analysis blood was withdrawn into centrifugation tubes containing $10 \%$ (by volume) of $3.8 \%$ acid citrate dextrose and prostaglandin $\mathrm{E}_{1}$ solution at $0{ }^{\circ} \mathrm{C}$. $\beta$-TG was measured by radioimmunoassay. ${ }^{15}$

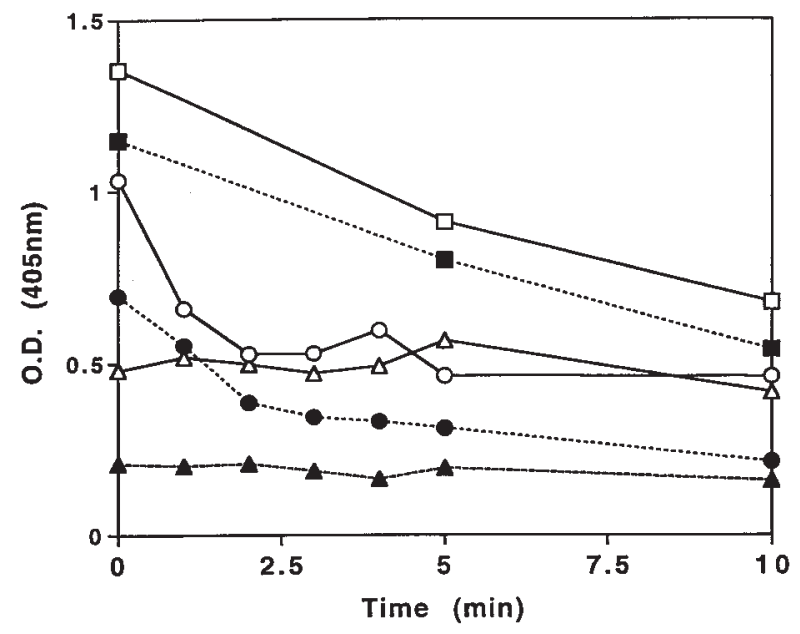

Fig 1. Comparison of anti-factor Xa activity in human and baboon plasma anticoagulated with $3.8 \%$ sodium citrate, heparin $(3.75 \mathrm{U} / \mathrm{mL})$ or enoxaparin $(17.5 \mathrm{U} / \mathrm{mL})$. At $10 \mathrm{~min}$ utes incubation, heparin and enoxaparin inhibited FXa equally; however, inhibition by heparin and enoxaparin was greater in baboon plasma than human plasma. Open symbols represent human plasma; solid symbols, baboon; squares, citrate; circles, heparin; triangles, enoxaparin.

Measurements of complement activation in baboon blood is difficult because of poor cross-reactivity with human antibodies. ${ }^{16,17}$ Assays for $\mathrm{C} 3 \mathrm{~b} / \mathrm{c}$ and $\mathrm{C} 4 \mathrm{~b} / \mathrm{c}$ have been developed and used successfully in studies of sepsis. ${ }^{16,17} \mathrm{C} 3 \mathrm{~b} / \mathrm{c}$ levels were assessed by radioimmunoassay with a monoclonal antiC3-28 antibody and a polyclonal ${ }^{125}$ I-anti-C3c antibody. ${ }^{16}$ $\mathrm{C} 4 \mathrm{~b} / \mathrm{c}$ was measured by a radioimmunoassay similar to that used for the determination of $\mathrm{C} 3 \mathrm{~b} / \mathrm{c}$, except that a monoclonal anti-C4-1 antibody and a polyclonal ${ }^{125} \mathrm{I}$-anti-C4 antibody were used. ${ }^{17}$ Both $\mathrm{C} 3 \mathrm{~b} / \mathrm{c}$ and $\mathrm{C} 4 \mathrm{~b} / \mathrm{c}$ results were expressed as a percentage of the amount of $\mathrm{C} 3 \mathrm{~b} / \mathrm{c}$ or $\mathrm{C} 4 \mathrm{~b} / \mathrm{c}$ present in normal baboon serum.

Elastase- $\alpha_{1}$ proteinase inhibitor levels were measured by 2 different enzyme-linked immunosorbent assay (ELISA) methods. The first assay (elastase- $\alpha_{1}$ proteinase inhibitor) was performed with commercial kits that used a polyclonal antibody to elastase as a capture antibody and conjugation with a antibody to $\alpha_{1}$-proteinase inhibitor complexed with alkaline phosphatase (Merck Immunoassay; Merck Inc, West Point, Pa). The second assay (elastase- $\alpha_{1}$-antitrypsin) used 2 monoclonal antibodies; one against elastase complexed with sephadex beads and another against $\alpha_{1}$-antitrypsin labeled by ${ }^{125} \mathrm{I}^{18}$

Plasma levels of $\mathrm{F}_{1.2}$ (Behring Diagnostics, Inc, Westwood, Mass), ${ }^{19}$ FPA (American Bioproducts, Parsipanny, NJ), ${ }^{20}$ TAT (Behring Diagnostics, Inc) ${ }^{21}$ were measured by ELISA with commercial assay kits.

Statistics. Data points represent the mean \pm SEM of measurements. Three-way analysis of variance (MANOVA) for repeated measures with the Bonferroni adjustment (SPSS for Windows 7.5; SPSS Inc, Chicago, Ill) was used for statistical 
Table I. Means and standard error of the means

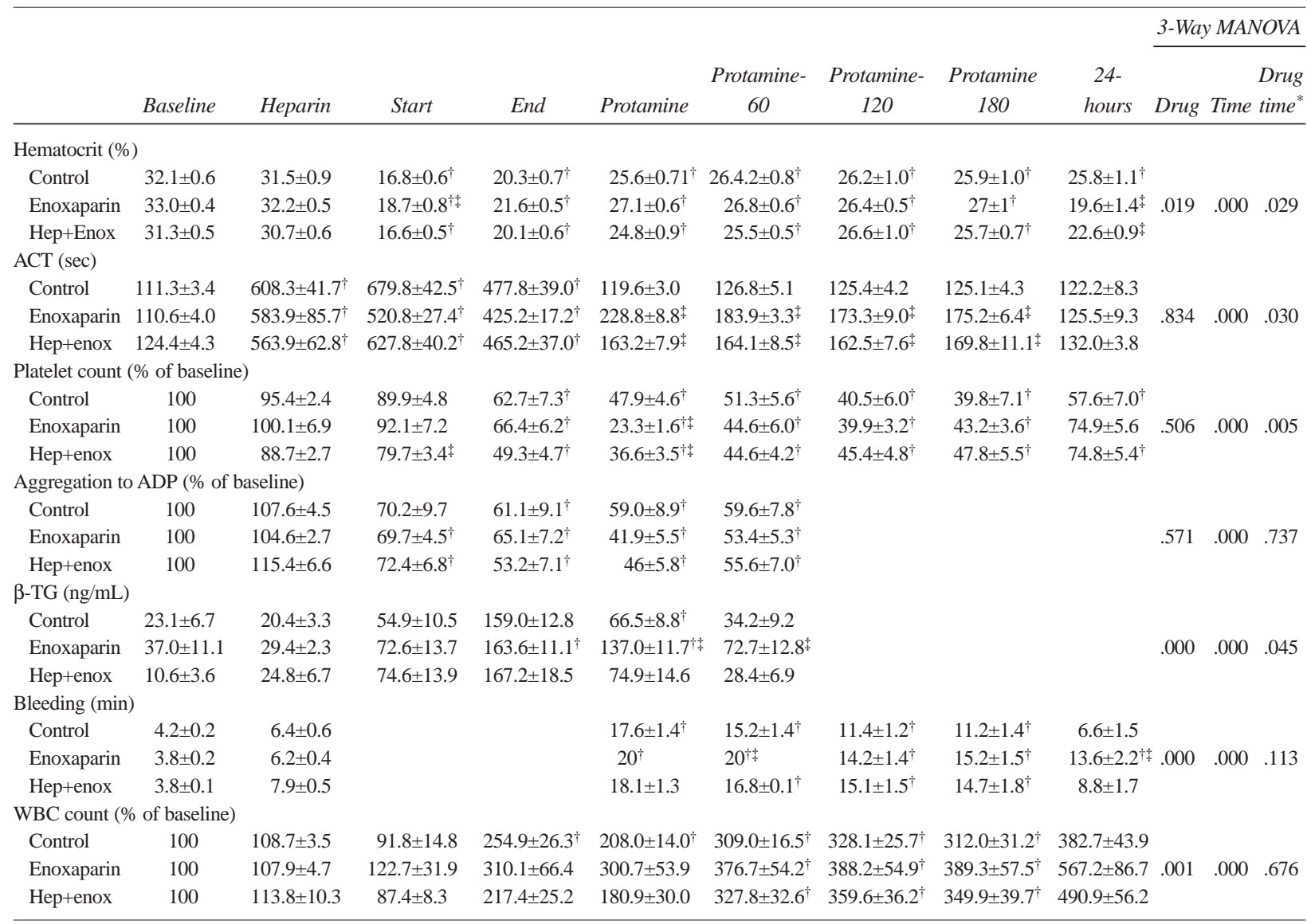

$A C T$, Activated clotting time; Hep, heparin; enox, enoxaparin; WBC, white blood count. $P$ values are given for 3-way MANOVA with Bonferroni adjustment for repeated measures.

${ }^{\dagger} P<.05$, within group $t$ statistic with Bonferroni correction, compared with baseline.

$\stackrel{\ddagger}{\ddagger}<.05$, between groups, statistic with Student unpaired $t$ test compared with control value when 2-way ANOVA group effect is $P<.05$.

analysis of time and group effects. When group effects were significant $(P<.05), 2$-way ANOVA between control and both enoxaparin groups (separately) was used to establish significant differences $(P<.05)$ between the control group and each experimental group. The unpaired $t$ statistic was used for specific comparisons between groups when the 2way ANOVA group effect was significant. The paired Student $t$ test with Bonferroni correction was used for analysis of differences within groups when the time effect was significant by 3-way MANOVA and 1-way ANOVA. Differences were considered statistically significant at the $P<.05$ level.

\section{Results}

Preliminary in vitro study. Both heparin and enoxaparin inhibited FXa as compared with citrate, even at the first sampling time. The inhibition at 0 time was greater with enoxaparin than heparin, but there was no difference in residual FXa activity at 10 minutes between anticoagulants for either human or baboon plas- ma. However, inhibition of FXa for both heparin and enoxaparin was greater in baboon plasma as compared with human plasma at nearly all time points (Fig 1). This indicates that both heparin and enoxaparin are more effective inhibitors of FXa in baboons than in human beings.

Both heparin and enoxaparin inhibited C1-s more than citrate, and there was no difference in the degree of inhibition between human and baboon plasma for enoxaparin. However, heparin produced greater inhibition of $\mathrm{C} 1-\mathrm{s}$ in human plasma than in baboon plasma after 10 minutes of incubation (data not shown).

In vivo studies. There were no significant differences between groups for arterial blood pressure, central venous pressure, pulmonary arterial and capillary wedge pressures, or cardiac output at any time point. During CPB, activated clotting times remained higher than 400 seconds for all animals (Table I). For 3 hours after protamine, activated clotting times remained sig- 


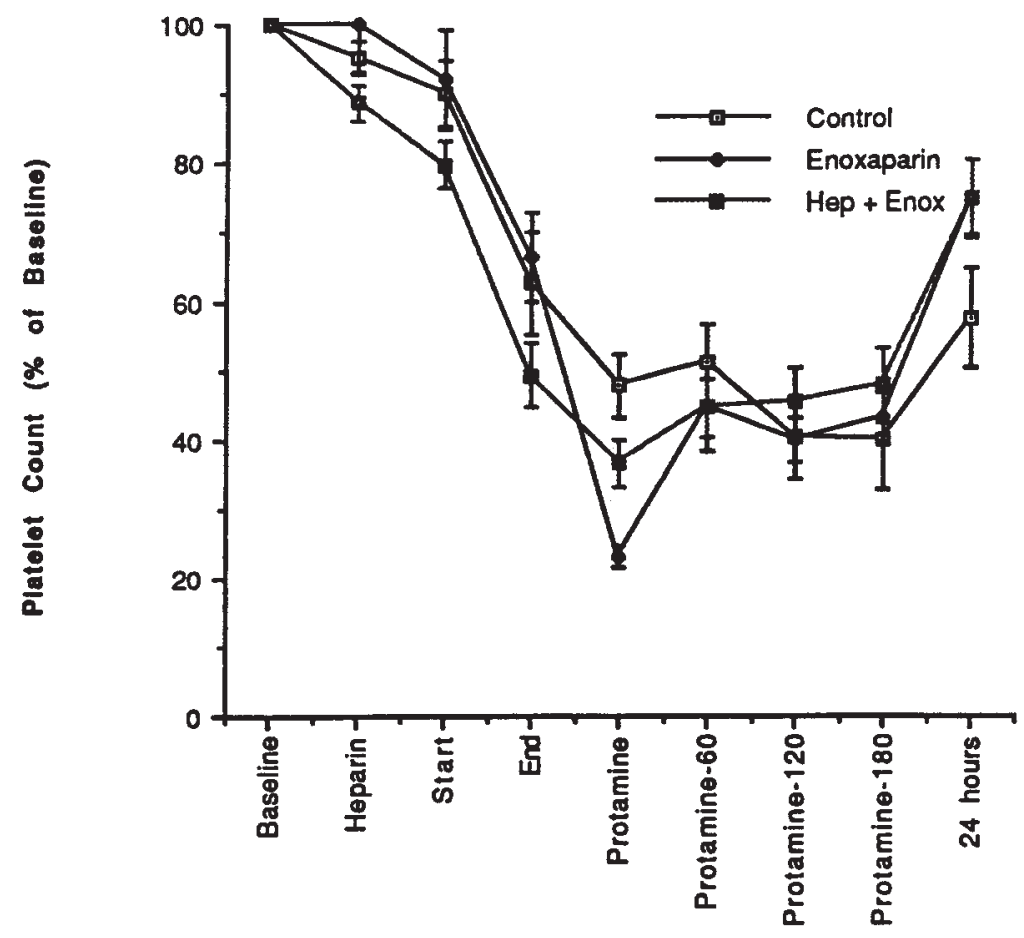

Fig 2. Platelet counts before, during, and after CPB. Platelet counts are corrected for hemaocrit and presented as percentage of baseline (before heparin) values. Data presented as mean \pm SEM. Open squares represent heparin group; diamonds, enoxaparin group; closed squares, combination group.

Table II. Means and standard error of the means

\begin{tabular}{|c|c|c|c|c|c|c|c|c|c|}
\hline & \multirow[b]{2}{*}{ Baseline } & \multirow[b]{2}{*}{ Heparin } & \multirow[b]{2}{*}{ Start } & \multirow[b]{2}{*}{ End } & \multirow[b]{2}{*}{ Protamine } & \multirow[b]{2}{*}{ Protamine-60 } & \multicolumn{3}{|c|}{ 3-Way MANOVA } \\
\hline & & & & & & & Drug & Time & Drug time \\
\hline \multicolumn{10}{|c|}{ Neutrophil elastase $(\mu \mathrm{L})$} \\
\hline Control & $77.5 \pm 4.9$ & $80.1 \pm 6.6$ & $146.2 \pm 10.3^{\dagger}$ & $145.7 \pm 10.3$ & $111.4 \pm 9.5$ & $111.6 \pm 8.6$ & \multirow{3}{*}{.000} & \multirow{3}{*}{.000} & \multirow{3}{*}{.653} \\
\hline Enoxaparin & $95.4 \pm 4.6$ * & $93.0 \pm 4.8$ & $155.6 \pm 9.7^{\dagger}$ & $154.2 \pm 7.5$ & $132.4 \pm 5.5^{\dagger}$ & $126.5 \pm 4.9^{\dagger}$ & & & \\
\hline Hep+ enox & $70.6 \pm 3.0$ & $86.9 \pm 12.9$ & $116.2 \pm 4.8^{\dagger \div}$ & $131.6 \pm 9.7$ & $112.3 \pm 10.1^{\dagger}$ & $104.6 \pm 8.1$ & & & \\
\hline \multicolumn{10}{|c|}{ c3b/c (\% of normal plasma amt) } \\
\hline Control & $1.28 \pm 0.13$ & $1.35 \pm 0.27$ & $5.70 \pm 0.58$ & $22.77 \pm 4.03^{\dagger}$ & $26.13 \pm 7.07^{\dagger}$ & $19.41 \pm 4.39^{\dagger}$ & \multirow{3}{*}{.004} & \multirow{3}{*}{.000} & \multirow{3}{*}{.238} \\
\hline Enoxaparin & $1.51 \pm 0.22$ & $1.27 \pm 0.17$ & $4.81 \pm 0.41$ & $17.29 \pm 2.79^{\dagger}$ & $14.53 \pm 1.82^{\dagger}$ & $12.04 \pm 1.13^{\dagger}$ & & & \\
\hline Hep+enox & $0.78 . \pm 0.12$ & $0.86 \pm 0.14$ & $9.28 \pm 2.05$ & $32.11 \pm 6.31^{\dagger}$ & $25.43 \pm 3.84^{\dagger}$ & $19.98 \pm 2.77^{\dagger}$ & & & \\
\hline \multicolumn{10}{|c|}{$\mathrm{c} 4 \mathrm{~b} / \mathrm{c}(\%$ of normal plasma amt) } \\
\hline Control & $2.28 \pm 0.29$ & $2.06 \pm 0.25$ & $2.93 \pm 0.29$ & $5.46 \pm 0.34$ & $13.43 \pm 6.24$ & $11.85 \pm 5.20$ & \multirow{3}{*}{.181} & \multirow{3}{*}{.000} & \multirow{3}{*}{.673} \\
\hline Enoxaparin & $3.41 \pm 0.68$ & $1.84 \pm 0.44$ & $2.25 \pm 0.38$ & $4.47 \pm 0.88$ & $5.73 \pm 1.20$ & $5.99 \pm 1.10$ & & & \\
\hline Hep+enox & $1.82 \pm 0.37$ & $1.79 \pm 0.47$ & $3.38 \pm 0.64$ & $7.85 \pm 2.2$ & $8.95 \pm 1.86^{\dagger}$ & $9.3 \pm 1.86^{\dagger}$ & & & \\
\hline \multicolumn{10}{|l|}{ FPA (ng/mL) } \\
\hline Control & $6.15 \pm 0.70$ & $2.79 \pm 0.41$ & $4.24 \pm 1.17$ & $11.45 \pm 3.74$ & $5.84 \pm 0.99$ & $6.91 \pm 3.12$ & \multirow{3}{*}{.006} & \multirow{3}{*}{.000} & \multirow{3}{*}{.000} \\
\hline Enoxaparin & $8.91 \pm 1.35$ & $2.01 \pm 0.35^{\dagger}$ & $2.01 \pm 0.45^{\dagger}$ & $1.52 \pm 0.17^{\dagger+}$ & $28.66 \pm 1.27^{\dagger \div}$ & $1.66 \pm 0.13^{\dagger}$ & & & \\
\hline Hep+enox & $8.34 \pm 2.43$ & $3.11 \pm 1.2$ & $2.92 \pm 0.59$ & $4.66 \pm 1.28$ & $5.76 \pm 1.41$ & $1.27 \pm 0.29^{\dagger}$ & & & \\
\hline \multicolumn{10}{|l|}{$\mathrm{F} 1.2(\mathrm{nmol} / \mathrm{L})$} \\
\hline Control & $1.03 \pm 0.09$ & $1.15 \pm 0.15$ & $1.18 \pm 0.17$ & $3.20 \pm 0.48^{\dagger}$ & $2.79 \pm 0.41^{\dagger}$ & $2.41 \pm 0.37^{\dagger}$ & \multirow{3}{*}{.000} & \multirow{3}{*}{.000} & \multirow{3}{*}{.000} \\
\hline Enoxaparin & $1.01 \pm 0.06$ & $0.92 \pm 0.07$ & $0.83 \pm 0.10$ & $1.03 \pm 0.19$ & $1.57 \pm 0.26^{\ddagger}$ & $1.46 \pm 0.18$ & & & \\
\hline Hep+enox & $1.09 \pm 0.16$ & $1.34 \pm 0.20$ & $1.34 \pm 0.24$ & $2.37 \pm 0.31^{\dagger}$ & $1.88 \pm 0.26$ & $1.49 \pm 0.21^{\ddagger}$ & & & \\
\hline \multicolumn{10}{|l|}{ TAT (mg/L) } \\
\hline Control & $8.27 \pm 1.62$ & $12.96 \pm 4.0$ & $9.53 \pm 2.16$ & $73.62 \pm 7.27^{\dagger}$ & $44.70 \pm 5.42^{\dagger}$ & $33.11 \pm 5.58^{\dagger}$ & \multirow{3}{*}{.000} & \multirow{3}{*}{.000} & \multirow{3}{*}{.000} \\
\hline Enoxaparin & $9.39 \pm 1.68$ & $7.38 \pm 0.79$ & $6.38 \pm 0.83$ & $16.97 \pm 4.28^{\ddagger}$ & $19.72 \pm 2.45^{\dagger+}$ & $13.54 \pm 1.67$ & & & \\
\hline Hep+enox & $7.21 \pm 2.21$ & $8.92 \pm 1.12$ & $9.19 \pm 1.62$ & $45.37 \pm 12.14^{\dagger \div}$ & $25.4 \pm 5.75^{\ddagger}$ & $15.52 \pm 3.53$ & & & \\
\hline
\end{tabular}

See Table I for an explanation of $P$ values and symbols. 


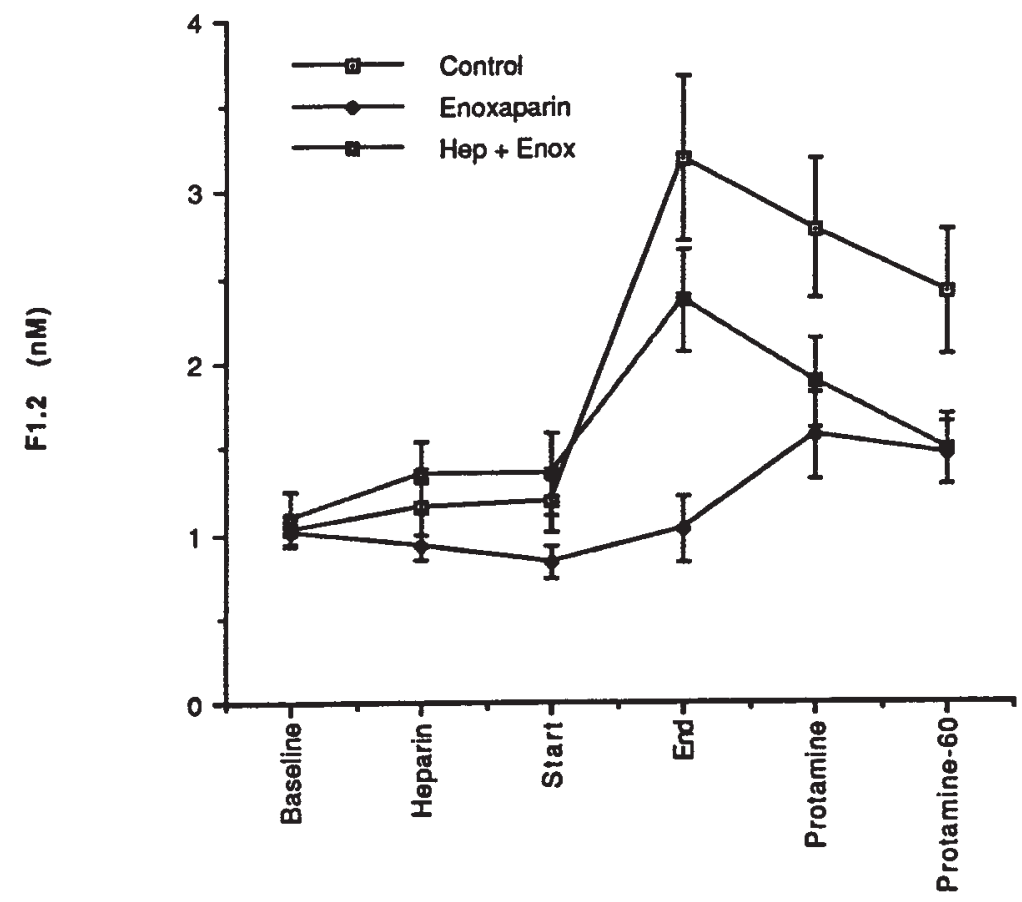

Fig 3. Blood prothrombin fragment (F1.2) before, during, and after CPB. Values are corrected for hematocrit. See Fig 2 for an explanation of the symbols.

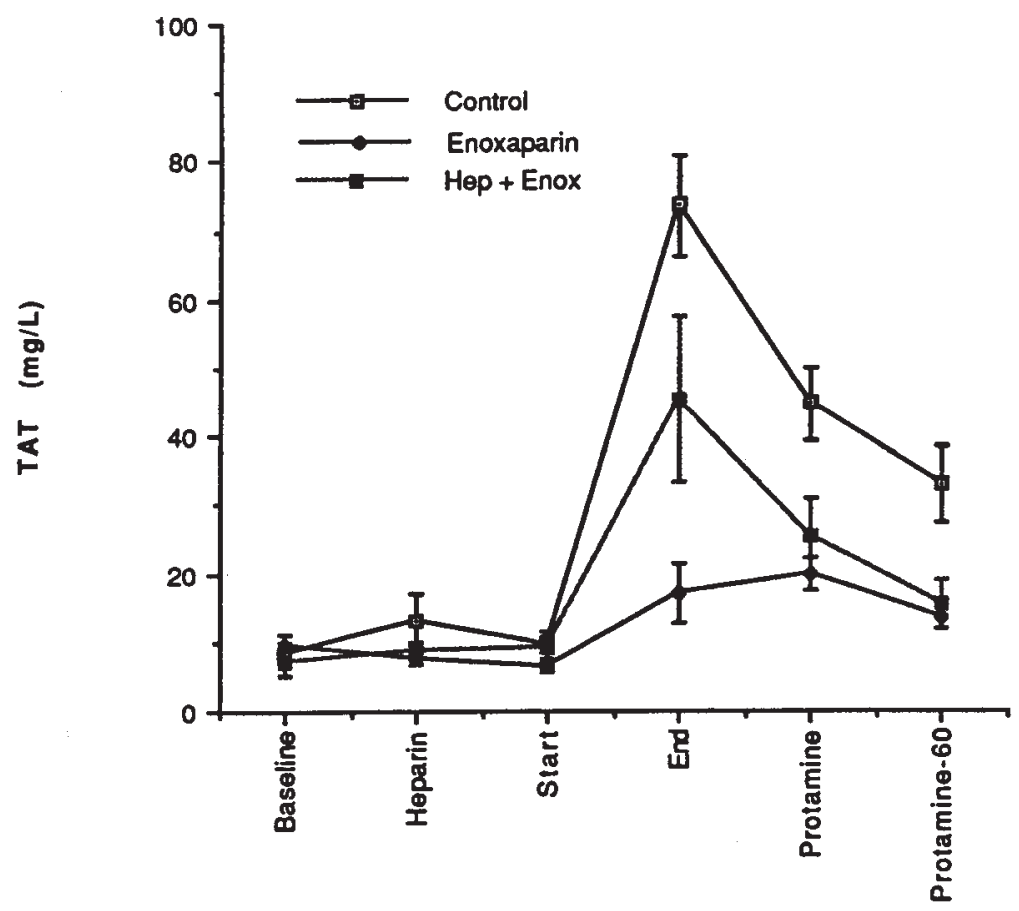

Fig 4. Plasma thrombin-antithrombin complex before, during, and after CPB. Values are corrected for hematocrit. See Fig 2 for an explanation of the symbols. 


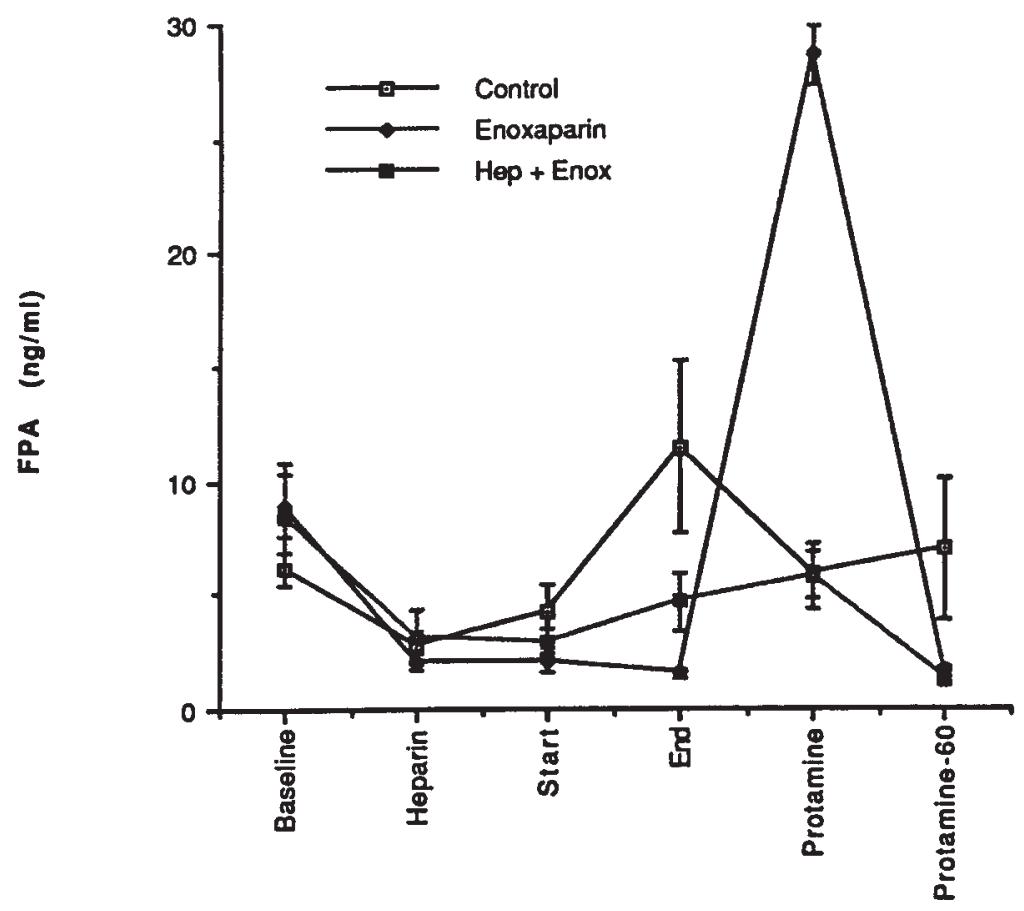

Fig 5. Blood fibrinopeptide-A before, during, and after CPB. Values are corrected for hematocrit. See Fig 2 for an explanation of the symbols.

nificantly elevated in both the enoxaparin and combination groups as compared with control animals but were similar at 24 hours (Table I).

Platelet counts did not differ between groups during CPB but were significantly lower than control in both groups that received enoxaparin at the time protamine was given, but not thereafter (Fig 2). The type of anticoagulant did not affect platelet function as measured by response to ADP. Plasma $\beta$-TG was significantly higher after CPB in animals that received only enoxaparin. White cell counts increased during CPB in all groups; there were no significant differences between groups.

Bleeding times remained significantly prolonged for more than 3 hours in all groups (Table I). In the enoxaparin group, however, bleeding times were still prolonged at 24 hours despite full protamine neutralization. ${ }^{22,23}$

No wound hematomas or postprotamine wound bleeding occurred in either the heparin or combination groups. However, hematomas developed at cutdown sites in 6 of 8 baboons in the enoxaparin group, 2 of which required evacuation.

Neutrophil elastase increased significantly during CPB in all groups, and although 3-way MANOVA indicated significant differences between groups, comparisons of each test group with the control group by 2way ANOVA were not significant (Table II). Similarly, complement $\mathrm{C} 3 \mathrm{~b} / \mathrm{c}$ also increased significantly during $\mathrm{CPB}$ in all groups but did not increase further with protamine. Group differences were significant by 3-way ANOVA but were not significantly different from the control group by 2-way ANOVA. C4b/c, a marker for the classic pathway, did not significantly change during CPB in any group (Table II).

By 3-way MANOVA both group and time effects and the interaction of group and time were significant for F1.2, TAT, and FPA (Table II). Enoxaparin significantly inhibited the rise in prothrombin fragment F1.2, TAT, and FPA during CPB as compared with control animals (Figs 3, 4, and 5; Table II). The combination of enoxaparin and heparin also attenuated the rise in these markers, but only TAT concentrations were significantly less than those measured in heparinized baboons. After protamine, FPA increased nearly 19 -fold in animals that were anticoagulated with enoxaparin, but neither TAT or F1.2 increased. This transitory rise in FPA was not observed in other groups and did not persist in the enoxaparin group.

\section{Discussion}

Both standard heparin and enoxaparin more completely inhibit FXa in baboon blood than in human blood, but C1-s inhibition with heparin is greater in 
human blood. Thus baboon data regarding thrombin formation in this study should be relevant to clinical CPB and cardiac operations at comparable levels of anticoagulation. Neither anticoagulant alters activation of complement or neutrophil elastase release in the present baboon study. This observation differs from our earlier in vitro study wherein enoxaparin, but not heparin, suppressed both complement activation and elastase release. ${ }^{7}$ As shown in the present study, suppression of complement activation in human blood by enoxaparin is not due to inhibition of $\mathrm{C} 1 \mathrm{~s}$ but may occur later in the cascade.

Complete suppression of thrombin generation during cardiac operations offers prospects of significantly reducing the thromboembolic and bleeding complications associated with these operations. Thrombin plays a central role in the regulation of coagulation and also in cell growth and migration. ${ }^{2}$ Thrombin directly activates platelets, forms fibrin, and activates key coagulation proteins (factors V, VIII, and XIII) but also activates protein $\mathrm{C}$ and fibrinolysis. ${ }^{24}$ Although standard heparin remains a prerequisite for $\mathrm{CPB}$ and cardiac surgery, thrombin is progressively generated in both wound ${ }^{25}$ and perfusion circuit and circulates during extracorporeal perfusion. ${ }^{1}$ Several alternatives to heparin have been investigated. These include coating perfusion circuits with ionic or covalently bound heparin, ${ }^{26,27} \mathrm{r}$ hirudin, ${ }^{28}$ heparinoids, ${ }^{29}$ and inhibitors of factors IXa ${ }^{30}$ and $\mathrm{Xa} .{ }^{7}$ None of these alternatives at the concentrations used reduce the generation or activity of thrombin. In contrast, enoxaparin attenuates thrombin formation and activity in the baboon model of extracorporeal circulation and in humans with deep vein thrombosis ${ }^{9}$; these observations encourage efforts to reduce circulating thrombin during cardiac operations.

Because platelets express a thrombin receptor on their external plasma membrane ${ }^{31}$ and are directly activated by thrombin, we expected to observe reduced platelet adhesion and alpha granule release of $\beta-\mathrm{TG}$ in animals anticoagulated with enoxaparin. This attenuation of platelet activation did not occur and probably reflects the fact that only small amounts of circulating thrombin are sufficient to activate platelets or that other agonists, such as ADP, contribute. Because the baboon model does not produce increases in D-dimer and plasmin-antiplasmin, ${ }^{13}$ fibrinolytic activity cannot be assessed in this model.

Protamine does not fully reverse the anticoagulant effect of enoxaparin and other low molecular weight heparins, ${ }^{8,10,22,23}$ and further studies are needed to elucidate the mechanism of this deficiency. In vitro $1: 1$ doses of protamine completely neutralize thrombin, ${ }^{22,23}$ but residual anti-factor Xa activity persists ${ }^{22}$ and is not fully reversed by higher doses. ${ }^{23}$ In this in vivo study with $\mathrm{CPB}$, however, immediately after protamine, FPA and $\beta$-TG significantly increase and platelet count decreases only in animals anticoagulated with enoxaparin. Sixty minutes after protamine, plasma FPA concentrations are not significantly different from other groups. By 24 hours, however, activated clotting times do not differ from control animals, but a functional deficiency of platelets remains and bleeding times are prolonged.

The increase in FPA levels with an accompanying slight rise in plasma TAT or F1.2 concentrations suggests a substantial increase in thrombin action with marginally enhanced thrombin generation after protamine. One explanation for this is that protamine preferentially neutralizes the inhibitory effect of enoxaparin on thrombin but not factor $\mathrm{Xa}^{22}$ The increase in plasma $\beta$-TG and the additional decline in platelet counts immediately afterwards is consistent with platelet activation by thrombin but does not explain the elevated bleeding times 24 hours later. Presence of thrombinactivated partially degranulated platelets in circulation may provide a partial explanation, but no continuing stimulus for thrombin formation exists early after $\mathrm{CPB}$ ends in the baboon model. Alternatively, direct inhibition of platelet function by enoxaparin or activation of platelets by enoxaparin-protamine complexes that are slowly cleared may interfere with platelet function and prolong bleeding times. Our data do not explain the mechanism of prolonged bleeding times 24 hours after protamine.

The failure to restore normal bleeding times after $\mathrm{CPB}$ and late wound bleeding observed with enoxaparin is consistent with clinical experience ${ }^{10-12}$ and negates use of enoxaparin for cardiac operations. Nevertheless, this study shows that a short-acting, quickly cleared, or metabolized factor Xa inhibitor offers the prospect of reducing thrombin formation and activity during open cardiac surgery.

We thank Sun Woo Park and Dr Andre Uzan for their contributions to this study and Rhone-Poulenc Rorer for the drug and financial support.

\section{REFERENCES}

1. Brister SJ, Ofosu FA, Buchanan MR. Thrombin generation during cardiac surgery: Is heparin the ideal anticoagulant? Thromb Haemost 1993;70:259-62.

2. Mann, KG. Prothrombin and thrombin. In: Colman RW, Hirsh J, Marder VJ, Salzman EW, editors. Hemostasis and thrombosis: basic principles and clinical practice. Philadelphia: JB Lippincott; 1994. p. 184-99. 
3. Rosenberg RD, Bauer KA. The heparin-antithrombin system: a natural anticoagulant mechanism. In: Colman RW, Hirsh J, Marder VJ, Salzman EW, editors. Hemostasis and thrombosis: basic principles and clinical practice. Philadelphia: JB Lippincott; 1994. p. 837-60.

4. Weitz JI, Hudoba M, Massel D, Maraganore J, Hirsh J. Clotbound thrombin is protected from inhibition by heparinantithrombin III but is susceptible to inactivation by antithrombin III-independent inhibitors. J Clin Invest 1990;86:385-91.

5. Colman RW, Marder VJ, Salzman EW, Hirsh J. Overview of hemostasis. In: Colman RW, Hirsh J, Marder VJ, Salzman EW, editors. Hemostasis and thrombosis: basic principles and clinical practice. Philadelphia: JB Lippincott; 1994. p. 3-18.

6. Vlasuk GP, Ramjit D, Fujita T, et al. Comparison of the in vivo anticoagulant properties of standard heparin and the highly selective factor $\mathrm{Xa}$ inhibitors antistasin and tick anticoagulant peptide (TAP) in a rabbit model of venous thrombosis. Thromb Haemost 1991;65:257-62.

7. Gikakis N, Khan MMH, Hiramatsu Y, et al. Effect of factor Xa inhibitors on thrombin formation and complement and neutrophil activation during in-vitro extracorporeal circulation. Circulation 1996;94(suppl):341-6.

8. Hirsh J, Levine MN. Low molecular weight heparin. Blood 1992; 79:1-17.

9. Grosset AB, Spiro TE, Beynon J, Rodgers GM. Enoxaparin, a low-molecular-weight heparin suppresses prothrombin activation more effectively than unfractionated heparin in patients treated for venous thromboembolism. Thromb Res 1997;86:349-54.

10. Massonnet-Castel S, Pelissier E, Bara L, et al. Partial reversal of low molecular weight heparin (PK10169) anti-Xa activity by protamine sulfate: in vitro and in vivo study during cardiac surgery with extracorporeal circulation. Haemostasis 1985;16:139-46.

11. Robitaille D, Leclerc JR, Laberge R, Sahab P, Atkinson S, Cartier R. Cardiopulmonary bypass with a low-molecular-weight heparin fraction (enoxaparin) in a patient with a history of heparin-associated thrombocytopenia. J Thorac Cardiovasc Surg 1992;103: 597-9.

12. Ganjoo AK, Harloff MG, Johnson WD. Cardiopulmonary bypass for heparin-induced thrombocytopenia: management with a heparin-bonded circuit and enoxaparin. J Thorac Cardiovasc Surg 1996;112:1390-2.

13. Hiramatsu Y, Gikakis N, Gorman JH, et al. A baboon model for hematologic studies of cardiopulmonary bypass. J Lab Clin Med 1997;130:412-20.

14. Carvalho ACA, Colman RW, Lees RS. Platelet function in hyperlipoproteinemia. N Engl J Med 1974;290:434-8.

15. Rucinski B, Niewiarowski S, James P, Walz DA, Budzynski Z. Antiheparin proteins secreted by human platelets: purification, characterization and radioimmunoassay. Blood 1979;53:47-62.

16. de Boer JP, Creasey AA, Chang A, et al. Activation of the complement system in baboons challenged with live escherichia coli; correlation with mortality and evidence for a biphasic activation pattern. Infect Immun 1993;61:4293-301.

17. Wolbink GJ, Bollen M, Baars JW, et al. Application of a monoclonal antibody against a neoepitope on activated $\mathrm{C} 4$ in an ELISA for the quantification of complement activation via the classical pathway. J Immunol Methods 1993;163:67-76.

18. Nuijens JH, Abbink JJ, Wachtfogel YT, et al. Plasma elastase-a antitrypsin and lactoferrin in sepsis: evidence for neutrophils as mediators in fatal sepsis. J Lab Clin Med 1992;119:159-67.

19. Pelzer H, Schwartz A, Stuber W. Determination of human prothrombin activation fragment $1+2$ in plasma with an antibody against synthetic peptide. Thromb Haemost 1991;65:153-7.

20. Amiral J, Walenga JM, Fareed J. Develpment and performance characteristics of a competitive enzyme immunoassay for fibrinopeptide A. Semin Thromb Hemost 1984;10:228-42.

21. Pelzer H, Schwarz A, Heimberger N. Determination of human thrombin-antithrombin III complex in plasma with an enzymelinked immunosorbent assay. Thromb Haemost 1993;50:740-4.

22. Woltz M, Weltermann A, Nieszpaur-Los M, et al. Studies on the neutralizing effects of protamine on unfractionated and low molecular weight heparin (Fragmin) at the site of activation of the coagulation system in man. Thromb Haemost 1995;73:439-43.

23. Van Ryn-McKenna J, Cai L, Ofosu FA, Hirsh J, Buchanan MR. Neutralization of enoxaparine-induced bleeding by protamine sulfate. Thromb Haemost 1990;63:271-4.

24. Levin EG, Marzec U, Anderson J, Harker LA. Thrombin stimulates tissue plasminogen activator release from cultured human endothelial cells. J Clin Invest 1984;74:1988-95.

25. Chung JH, Gikakis N, Drake TA, Colman RW, Edmunds LH Jr. Pericardial blood activates the extrinsic coagulation pathway during clinical cardiopulmonary bypass. Circulation 1996;93:2014-8.

26. Gorman RC, Ziats NP, Gikakis N, et al. Surface-bound heparin fails to reduce thrombin formation during clinical cardiopulmonary bypass. J Thorac Cardiovasc Surg 1996;111:1-12.

27. Ovrum E, Am Holen E, Tangen G, et al. Completely heparinized cardiopulmonary bypass and reduced systemic heparin: clinical and hemostatic effects. Ann Thorac surg 1995;60:365-71.

28. Bernabei AF, Rao AK, Niewiarowski S, Colman RW, Sun L, Edmunds LH Jr. Recombinant desulfatohirudin as a substitute for heparin during cardiopulmonary bypass. J Thorac Cardiovasc Surg 1994;284:381-2.

29. Wilhelm MJ, Schmid C, Kececioglu D, Mollhoff T, Ostermann H, Scheld JJ. Cardiopulmonary bypass in patients with heparininduced thrombocytopenia using Org 10172. Ann Thorac Surg 1996;61:920-4.

30. Spanier TB, Oz MC, Minanov OP, Simantov R, Kisiel W, Stern $\mathrm{DM}$, et al. Heparinless cardiopulmonary bypass with active-site blocked factor IXa: a preliminary study on the dog. J Thorac Cardiovasc Surg 1998;115:1179-88.

31. Coughlin SR, Vu T-K H, Hung DT, Wheaton VI. Characterization of a functional thrombin receptor. J Clin Invest 1992;89:351-5. 